\title{
School and Community - based Youth Mental Health Intervention Studies in India: A Scoping Review
}

\section{Review}

\section{Ragaviveka Gopalan, C Sangeetha, P Ramakrishnan, Vijaya Raghavan}

- Schizophrenia Research Foundation, R/7A, North Main Road, Anna Nagar West Extension, Chennai - 600 101,

Tamil Nadu, India.

\section{Abstract}

\section{BACKGROUND}

About $70 \%$ of mental disorders emerge in late childhood and young peo-ple bear the burden of these disorders throughout life. Yet, to date there has been com-paratively little research on mental health interventions for young people in India and not many attempts have been made to collate the existing literature. This systematic review aims to synthesize the available evidence on school- and community-based mental health interventions for young people in India.

\section{METHODS}

A range of major electronic databases were searched systematically, and the abstracts of relevant papers were independently examined for possible inclusion. Selected papers were read in full text and a standardized set of data items were extracted.

\section{RESULTS}

Four papers met inclusion criteria for the analysis; two studies of school-based interventions for adolescents and two studies evaluating out-of-school community interventions for youth were reviewed. The quality of evidence from the interventions in Indian school and community settings were poor. While two studies evidence the effectiveness of a school-based life skills programme and a community based multicomponent intervention designed to promote youth health, two other studies do not offer sufficient data.

\section{CONCLUSION}

The review findings indicate that the number of interventional studies conducted in India to address youth mental health issues are very limited. Hence, it is extremely difficult to ensure the feasibility and effectiveness of school and community-based interventions in India. Further research is warranted to establish whether interventions promoting youth mental health people can be implemented effectively in Indian settings with positive mental health outcomes. Given the possibility of a huge population of young people at-risk or experiencing mental disorders, evidence for the efficacy of youth mental health interventions is crucial.

Corresponding author:

Vijaya Raghavan

Schizophrenia Research Foundation,

R/7A, North Main Road, Anna Nagar West Extension, Chennai - 600 101, Tamil Nadu, India.

Email: vijayaraghavan@scarfindia.org

\section{KEY WORDS: Youth Mental Health, Intervention, School, Community, Review, India}




\section{INTRODUCTION}

Mental health is fundamental to good health and wellbeing and influences social and economic outcomes across the lifespan. World Health Organization (WHO) defines 'Adolescents' as individuals in the 10-19 years age group and 'Youth' as the 15-24 years age group and 'Young People' covers the age range 10-24 years. ${ }^{1}$ Childhood and adolescence are crucial periods for laying the foundations for healthy development and good mental health. ${ }^{2}$ It is estimated that $10-20 \%$ of young people worldwide experience mental health problems. ${ }^{3}$ Poor mental health in childhood is associated with health and social problems such as school failure, delinquency and substance misuse, and increases the risk of poverty and other adverse outcomes in adulthood. ${ }^{4}$ Interventions that promote positive mental health equip young people with the necessary life skills, supports and resources to fulfill their potential and overcome adversity. ${ }^{5}$ Systematic reviews of the international evidence, which come predominantly from high income countries (HICs), show that comprehensive mental health promotion interventions carried out in collaboration with families, schools and communities, lead to improvements not only in mental health but also improved social functioning, academic and work performance, and general health behaviors. ${ }^{6}$

Despite the recognition of the importance of mental health promotion for children and adolescents, mental health remains a neglected public health issue, especially in low and middle-income countries (LAMICs). ${ }^{7}$ Mental health is inequitably distributed as people living in poverty and other forms of social disadvantage bear a disproportionate burden of mental disorders and their adverse consequences. ${ }^{8}$ There is increasing recognition of the relevance of mental health to global development strategies, and in particular to the achievement of the Millennium Development Goals (MDGs), including improving child and maternal health, universal education, combating HIV/AIDS and other diseases, and eradicating poverty. ${ }^{9}$ As $90 \%$ of the world's children and adolescents live in LAMICs, where they constitute up to $50 \%$ of the population, there is an urgent need to address the mental health of young people as part of the wider health promotion and development agenda. ${ }^{10}$

Schools are one of the most important community settings for promoting the mental health of young people The school setting provides a forum for promoting emotional and social competence as well as academic learning and offers a means of reaching the significant number of young people who experience mental health problems. ${ }^{11}$ Educational opportunities throughout life are associated with improved mental health outcomes. The promotion of emotional health and wellbeing is a core feature of the WHO's Health Promoting Schools initiative. ${ }^{12}$ There is good evidence that mental health promotion programs in schools, especially those adopting a whole school approach, lead to positive mental health, social and educational outcomes. ${ }^{13}$ Programs incorporating life skills, social and emotional learning and early interventions to address emotional and behavioral problems, produce long-term benefits for young people, including improved emotional and social functioning, positive health behaviors, and improved academic performance. ${ }^{14}$

India has more than $50 \%$ of its population below the age of 25 and more than $65 \%$ be-low the age of $35 .{ }^{15}$ It is expected that, in 2020, the average age of an Indian will be 29 years. According to 'World Population Prospects: The 2015 revision' Population Data-base of United Nations Population Division, India has the world's highest number of 10 to 24 - year-olds, with 242 million. ${ }^{16}$ As per India's Census 2011, Youth (15-24 years) in India constitutes one-fifth (19.1\%) of India's total population. According to World Health Organization (WHO), at least 20 per cent of young people are likely to experience some form of mental illness such as depression, mood disturbances, substance abuse, suicidal behaviors, eating disorders and others. ${ }^{17}$ This translates into a huge population of young people are at-risk or experiencing mental disorders in India and leading to significant morbidity, mortality, individual and societal costs. Moreover, the limited availability of resources for the treatment of mental health issues in general and especially for young people and stigma against mental disorders in the community has compounded the youth mental health issues as a major health problem in India.

To date there has been comparatively little research on school and community-based mental health promotion interventions for young people in Indian settings and no sys-tematic attempt to synthesize the evidence from such settings except one. ${ }^{18}$ Hence, the objective of this review to collate the available literature on adolescent and youth mental health interventions from India in different settings. 


\section{MATERIALS AND METHODS}

\section{SEARCH STRATEGY}

Academic databases including PubMed, Scopus, and Cochrane database of systematic reviews were searched. Additional sources included Google Scholar and reference list of relevant articles, book chapters and reviews. The electronic search strategy used across all databases is as follows: ("adolescent" or "youth") and ("mental health" or "mental illness" or "mental disorders" or "behavioral problems") and ("school" or "college" or "community or "population") and ("promotion" or "prevention" or "treatment" or "interventions"). The timeframe of the search was set between 1990 and 2018.

\section{INCLUSION AND EXCLUSION CRITERIA}

Inclusion criteria: 1. Studies from India 2. Target population - adolescents $(10-18)$ and youth (15 - 24) 3. Intervention studies. Exclusion criteria: 1. Crosssectional studies 2 . Review articles and commentaries

\section{STUDY SELECTION AND DATA COLLECTION}

Using the search strategy described above, all titles and abstracts retrieved were scanned for relevance. Duplicates, irrelevant articles, and articles that did not meet the inclusion criteria were removed. Full text papers were obtained for studies that were selected for inclusion. Studies were subsequently selected relating to young people and were classified according to (i) school-based programs (ii) community-based programs for adolescents.

\section{RESULTS}

The results of the search and study selection are shown in Fig 1. We could find four studies demonstrating mental health interventions in adolescents in India. The reviewed articles were classified as school- and community-based interventions for youth mental health and presented in Table 1 and Table 2. A couple of these studies have described interventions that have made use of local resources as well as terminology suited to local context. ${ }^{19,20}$ In a study by Nair et al., ${ }^{20}$ a communitybased multicomponent intervention delivered by basic health workers was found to be acceptable and feasible. In another study by same authors (2013), 'sex education' as an intervention was accepted more when it was called 'family life education. ${ }^{19}$ Srikala and Kishore (2010) described the success of life skills education in schools in improving the coping skills, self-esteem and adjustment of adolescents in school with no observed differences in the psychopathology than the control group. ${ }^{21}$ In a recent study, Balaji et al., has examined the effectiveness of community based interventions to promote youth mental health and found significant improvement in mental health issues among the youth in the community. ${ }^{22}$

\section{DISCUSSION}

The aim of this narrative review is to synthesize the major findings from the Indian studies that have examined the school- and community- based interventions aimed at improving youth mental health.

One of the major findings from the study is the sparse number of published research articles from India that has examined the youth mental health interventions. So far, only four interventions have been published from India. When compared with number of similar studies from the other parts of the world, this is far less. Most of the studies done in the western world are school-based interventions for the adolescents and young people. Most of the interventions were specifically addressed for a particular disorder such as depression, anxiety and others. $^{23}$

As the review highlights, there are only four interventional studies that have been con-ducted in India to promote youth mental health in school- and community-settings. Moreover, the study design, implementation and outcome measures in two of these studies are not clear or not measured.19,20 This reduces the usefulness and the replica-bility in other settings. The generalizability of the findings of these studies is limited due to the non-representative sample, various biases (e.g. common variance effect, self-report bias, etc.) and purposive sampling. The interventions assessed in these studies have not been replicated in other parts of India to ensure their feasibility and effectiveness.

Schools are a unique resource to help promote and improve the mental health of young people as it is where large cohorts of children and adolescents can be reached. Especially in LAMICs such as India, the increasing enrolment rates place schools in a crucial position to support mental health in children and adolescents as in high -income countries. ${ }^{24}$ Teachers can be trained to identify and remedy mental health difficulties in schoolaged children, and they can be actively involved in mental health programmes. ${ }^{25}$ However, further research is warranted to determine whether teachers are likely to have a significant impact on the Indian youth, and the resources and the willingness of teachers to take on an additional burden is another challenge to be addressed. Nevertheless, a specialist staff can be hired, or a 
dedicated individual can be trained to deliver effective multicomponent interventions targeting a range of behavioral and emotional problems. Or, all children within a school can be screened to determine their true risk status and those who are deemed to be at-risk could be provided with an individualized assessment to determine their needs. Accompanying interventions could be provided at any point. ${ }^{26}$ At the very least, schools can promote positive mental health and create resilience, providing the young person with resources to thrive and, in adverse conditions, to cope by buffering negative stressors. ${ }^{27}$

However, according to the Census of India, in 2011, out of a total of 208 million children between $6-13$ years, $18.3 \%$ were out-of-school. ${ }^{28}$ This translates into about 38 million children, a huge population of children being unable to access school-based interventions. Therefore, using the concept of community-based interventions may be a turning point for young people out-of-school, especially for those who are from a less than optimum family and neighborhood. Such interventions could be used to reach out to individuals in their local community settings or target the community attitudes (e.g., stigma) that affect some component of the burden of mental health problems in young people. ${ }^{29}$ For example, non-specialists could be trained to do home visits for common mental disorders in young people, ${ }^{30}$ groupbased interventions could be delivered in workplaces ${ }^{31}$ employing youth or, the internet could be used to deliver help for mental health problems in rural settings with poor accessibility to face-to-face mental health services. $^{32}$

In several countries, governmental and nongovernmental agencies offer multiple pro-grammes oriented towards youth development. In India, for instance, the Rashtriya Kishor Swasthya Karyakram (RKSK) was launched to address the health needs of adolescents, where community-based health interventions are delivered through peer facilitators. ${ }^{33}$ Similarly, Schizophrenia Research Foundation (SCARF), a not-for-profit organization based in Chennai, in association with World Psychiatric Association (WPA) has launched school based interventions to promote adolescent and youth mental health. ${ }^{34}$ Government of Kerala has launched an Integrated Child Protection Scheme, under the purview Social Justice department, to comprehensively promote child rights and improve mental health and behaviour through multi-pronged approach. ${ }^{35}$ However, less than a third of countries have a separate entity in charge of mental health programmes for young people; mainly due to factors such as inadequate funding, lack of trained force and stigma. Therefore, to promote youth mental health in LMICs, a single most feasible option would be to integrate mental health interventions into already existing youth programmes, including those in the health (e.g., reproductive and sexual health) and outside health (e.g., education) sectors. The RKSKlooks beyond reproductive health, addressing mental health issues and substance abuse, but there is almost no data to indicate the longterm effects of the programme on young people; this makes it difficult to establish whether such communitybased systems are effective. Future intervention studies should thus collect data for the impact of such national or non-governmental programmes on youth. Afterall, investments in young people yields high returns in terms of adult disorder prevented or less severe, economic advantage for healthy individuals and achievement of development goals in respective countries. ${ }^{3}$

According to the World Health Organization, mental health issues have become one of the leading causes of disability among youth.36 About $70 \%$ of mental disorders onset prior to the age of 25 and young people bear the burden of these disorders and their long-lasting effects throughout life. ${ }^{37}$ If these mental health conditions are left untreated, they can impede all aspects of health, including emotional well-being and social development. ${ }^{38}$ Consequently, leaving the youth vulnerable to social isolation, stigmatization, educational difficulties, risk-taking behaviors and physical ill-health and thus, hindering their ability to contribute to the society. Such mental health problems also increase the risk of poverty and other adverse outcomes in adulthood.4 Seeking for appropriate help is widely recognized as a generic protective factor, and early treatment and prevention are vital for youth because of the high prevalence of mental health issues at this stage of life. ${ }^{39}$ It is estimated that India comprises about 242 million young people, making it home to the largest number of youths in the world. ${ }^{16}$ Given such a large proportion of young people, and the prevailing burden and impact of mental health issues on them, it is essential that effective interventions are identified and implemented in India.

\section{ACKNOWLEDGEMENT}

We like to thank Pooja $S$ for her help with finding the articles for the review. Author, Raghavan, was supported by India-US Fogarty Training in Chronic Non-Communicable Disorders \& Diseases Across Lifespan Grant \# 1D43TW009120 (Raghavan, Fellow; LB Cottler, PI). 


\section{References}

1 Adolescent health [Internet]. [cited 2020 Mar 10]. Available from: https://www.who.int/westernpacific/ health-topics/adolescent-health

2 Herrman H, Jané-Llopis E. The status of mental health promotion. Public Health Rev. 2012;34(2):6.

3 Kieling C, Baker-Henningham H, Belfer M, Conti G, Ertem I, Omigbodun O, et al. Child and adolescent mental health worldwide: evidence for action. The Lancet. 2011;378(9801):1515-1525.

4 Jenkins R, Baingana F, Ahmad R, McDaid D, Atun R. Social, economic, human rights and political challenges to global mental health. Ment Health Fam Med. 2011;8(2):87.

5 Durlak JA, Wells AM. Primary prevention mental health programs for children and adolescents: A metaanalytic review. Am J Community Psychol. 1997;25(2):115-152.

6 Jané-Llopis E, Barry M, Hosman C, Patel V. Mental health promotion works: a re-view. Promot Educ. 2005;12(2_suppl):9-25.

7 Lund C, Breen A, Flisher AJ, Kakuma R, Corrigall J, Joska JA, et al. Poverty and common mental disorders in low and middle income countries: a systematic re-view. Soc Sci Med. 2010;71(3):517-528.

8 Patel V, Lund C, Hatherill S, Plagerson S, Corrigall J, Funk M, et al. Mental disor-ders: equity and social determinants. Equity Soc Determinants Public Health Pro-gramme. 2010;115.

9 Miranda JJ, Patel V. Achieving the Millennium Development Goals: does mental health play a role? PLoS Med. 2005;2(10):e291.

10 Patel V, Flisher AJ, Nikapota A, Malhotra S. Promoting child and adolescent mental health in low and middle income countries. J Child Psychol Psychiatry. 2008 Mar;49(3):313-334.

11 Zins JE. Building academic success on social and emotional learning: What does the research say? Teachers College Press; 2004.

12 Organization WH. Creating an environment for emotional and social well-being: an important responsibility of a health promoting and child-friendly school. 2003;

13 Lister-Sharp D, Chapman S, Stewart-Brown S, Sowden A. Health promoting schools and health promotion in schools: two systematic reviews. 1999;

14 Tennant R, Goens C, Barlow J, Day C, Stewart-Brown S. A systematic review of reviews of interventions to promote mental health and prevent mental health prob-lems in children and young people. J Public Ment Health. 2007;6(1):25-32.

15 Census of India: Age Structure And Marital Status [Internet]. [cited 2018 Jul 13]. Available from: http:// censusindia.gov.in/Census_And_You/age_structure_and_marital_status.aspx

16 The World Population Prospects: 2015 Revision [Internet]. 2015 [cited 2018 Feb 13]. Available from: world-population-prospects-2015-revision.html

17 Sunitha S, Gururaj G. Health behaviours \& problems among young people in India: cause for concern \& call for action. Indian J Med Res. 2014;140(2):185-208.

18 Aggarwal S, Berk M. Evolution of adolescent mental health in a rapidly changing socioeconomic environment: a review of mental health studies in adolescents in India over last 10 years. Asian J Psychiatry. 2015;13:3-12.

19 Nair MKC, Leena ML, Menon P, George B, Indira MS, Russell PSS. ARSH 8: Family life education and counseling: a school based model. Indian J Pediatr. 2013;80(Suppl 2):S234-239.

20 Nair MKC, Leena ML, George B, Sunitha RM, Prasanna GL, Russell PS. A pan-chayat level primary-care approach for adolescent services. Indian J Pediatr. 2012;79(Suppl 1):S6-10. 
21 Srikala B, Kishore KKV. Empowering adolescents with life skills education in schools - School mental health program: Does it work? Indian J Psychiatry. 2010;52(4):344-349.

22 Balaji M, Andrews T, Andrew G, Patel V. The acceptability, feasibility, and effec-tiveness of a populationbased intervention to promote youth health: an exploratory study in Goa, India. J Adolesc Health Off Publ Soc Adolesc Med. 2011;48(5):453-460.

23 O'Reilly M, Svirydzenka N, Adams S, Dogra N. Review of mental health promotion interventions in schools. Soc Psychiatry Psychiatr Epidemiol. 2018;53(7):647-662.

24 Fazel M, Hoagwood K, Stephan S, Ford T. Mental health interventions in schools in high-income countries. Lancet Psychiatry. 2014;1(5):377-387.

25 Hendren R, Birrell Weisen R, Orley JH, Organization WH. Mental health pro-grammes in schools. Geneva: World Health Organization; 1994.

26 Dowdy E, Ritchey K, Kamphaus RW. School-based screening: A population-based approach to inform and monitor children's mental health needs. School Ment Health. 2010;2(4):166-176.

27 Weare K, Nind M. Mental health promotion and problem prevention in schools: what does the evidence say? Health Promot Int. 2011;26(Suppl_1):i29-i69.

28 India's missing millions of out of school children: A case of reality not living up to estimation? [Internet]. [cited 2019 Jul 14]. Available from: https://www.oxfamindia.org/featuredstories/indias-missing-millionsout-school-children-case-reality-not-living-estimation

29 Bruce ML, Smith W, Miranda J, Hoagwood K, Wells KB. Community-based inter-ventions. Ment Health Serv Res. 2002;4(4):205-214.

30 Jordans MJD, Komproe IH, Tol WA, Susanty D, Vallipuram A, Ntamatumba P, et al. Practice-driven evaluation of a multi-layered psychosocial care package for chil-dren in areas of armed conflict. Community Ment Health J. 2011;47(3):267-277.

31 Bass JK, Annan J, McIvor Murray S, Kaysen D, Griffiths S, Cetinoglu T, et al. Con-trolled trial of psychotherapy for Congolese survivors of sexual violence. N Engl J Med. 2013;368(23):2182-2191.

32 Griffiths KM, Christensen H. Internet-based mental health programs: A powerful tool in the rural medical kit. Aust J Rural Health. 2007;15(2):81-87.

33 Rashtriya Kishor Swasthya Karyakram (RKSK) | National Health Portal Of India [Internet]. [cited 2019 Jul 14]. Available from: https://www.nhp.gov.in/rashtriya-kishor-swasthya-karyakram-rksk_pg

34 Stories N. Chennai workshop links mental health professionals to city schools [In-ternet]. WPA. 2020 [cited 2020 Mar 10]. Available from: https://www.wpanet.org/post/first-practice-transformationworkshop-in-chennai-links-mental-health-professionals-to-city-schools

35 ORC - OUR RESPONISBILITY TO CHILDREN [Internet]. [cited 2020 Mar 10]. Available from: http:// www.orcindia.org/index.html

$36 \mathrm{WHO}$ | Child and adolescent mental health policies and plans [Internet]. WHO. [cit-ed 2019 Jul 14]. Available from: https://www.who.int/mental_health/policy/services/essentialpackage1v11/en/

37 Kendall PC, Safford S, Flannery-Schroeder E, Webb A. Child anxiety treatment: outcomes in adolescence and impact on substance use and depression at 7.4-year follow-up. J Consult Clin Psychol. 2004;72(2):276287.

38 Kutcher S, Venn D. Why youth mental health is so important. Medscape J Med. 2008;10(12):275.

39 Rickwood DJ, Deane FP, Wilson CJ. When and how do young people seek professional help for mental health problems? Med J Aust. 2007;187(Suppl_7):S35-S39. 
Fig 1. Search results from original search of youth mental health interventions from India

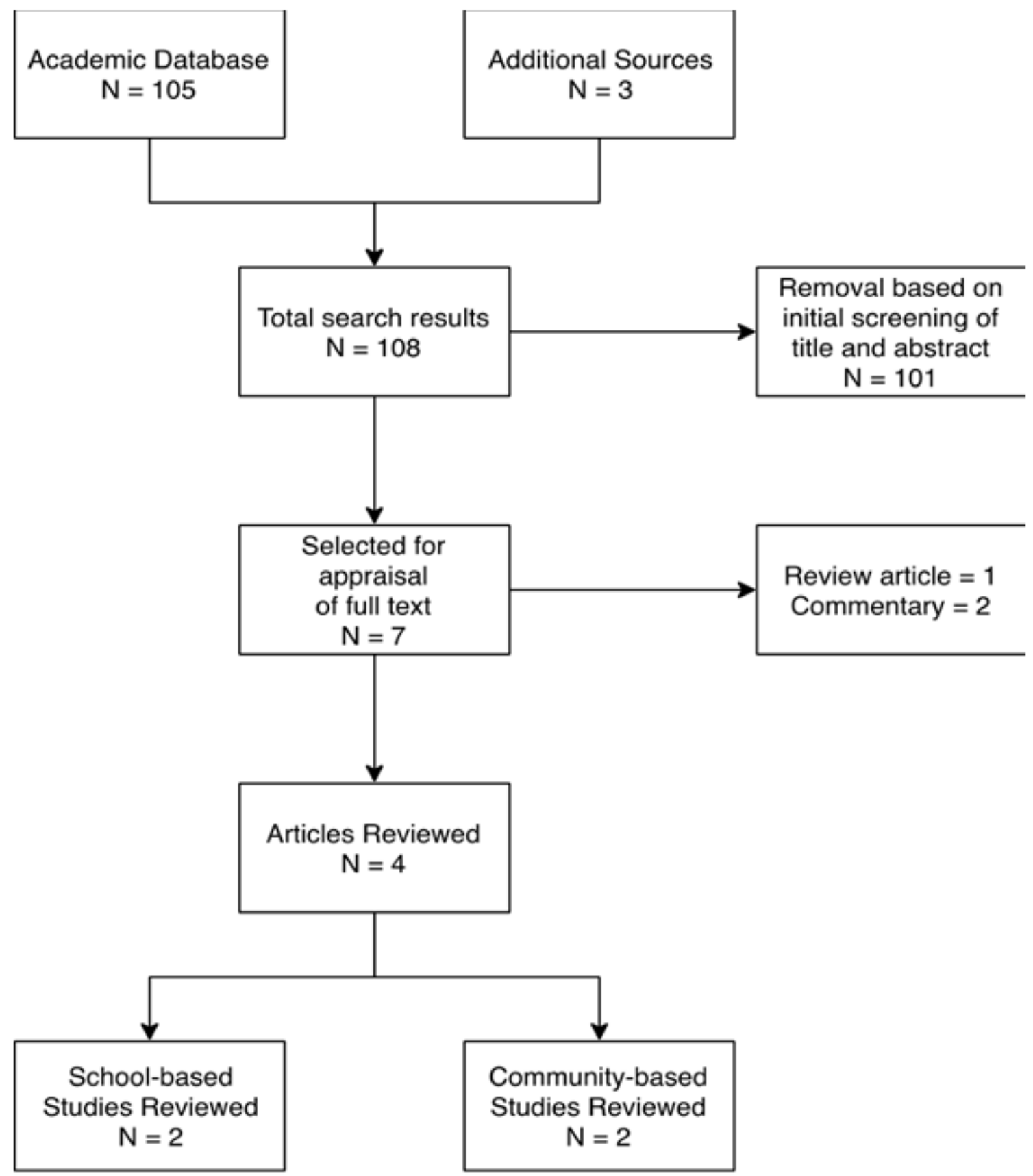


Table 1. School-based youth mental health interventions in India

\begin{tabular}{|c|c|c|c|c|}
\hline $\begin{array}{c}\text { Study name and } \\
\text { author }\end{array}$ & Target group & $\begin{array}{c}\text { Type of } \\
\text { intervention and } \\
\text { duration }\end{array}$ & Study design & Outcomes \\
\hline $\begin{array}{l}\text { Life Skills } \\
\text { education } \\
\text { programme; } \\
\text { Srikala \& Kumar, } \\
2010[20]\end{array}$ & $\begin{array}{l}\text { Youth } \\
\text { (14-16 years) in } \\
\text { secondary schools }\end{array}$ & $\begin{array}{l}\text { Lifeskills education } \\
\text { intervention. Skills } \\
\text { taught include } \\
\text { critical thinking, } \\
\text { decision making, } \\
\text { problem solving, } \\
\text { communication, and } \\
\text { coping skills. } \\
\text { Implemented once a } \\
\text { week, (1 hr) over } 12 \\
\text { to } 20 \text { sessions during } \\
\text { one academic year } \\
\text { Sessions taught by } \\
\text { class teacher }\end{array}$ & $\begin{array}{l}\text { Quasi- } \\
\text { Experimental - } \\
\text { random selection } \\
\text { of schools with } \\
\text { matched control } \\
\text { design: } \\
\mathrm{N}=1028 \\
\text { adolescents } \\
\text { Control received } \\
\text { standard civic } \\
\text { education classes }\end{array}$ & $\begin{array}{l}\text { Significant } \\
\text { improvement in: } \\
\text { - self-esteem } \\
\text { - perceived self } \\
\text { - efficacy } \\
\text { - pro-social behavior } \\
\text { - perceived adequate } \\
\text { coping } \\
\text { Participants had } \\
\text { significant: } \\
\text { - better adjustment with } \\
\text { teachers } \\
\text { - better adjustment in } \\
\text { school } \\
\text { - improved classroom } \\
\text { behaviour } \\
\text { No change in adjust- } \\
\text { ment with parents and } \\
\text { peers }\end{array}$ \\
\hline $\begin{array}{l}\text { ARSH 8: Family } \\
\text { Life Education and } \\
\text { Coun-seling; Nair } \\
\text { et al., } 2013 \text { [19] }\end{array}$ & 16 years of age & $\begin{array}{l}\text { Teenage screening } \\
\text { questionnaire } \\
\text { Trivandrum (TSQ-T) } \\
\text { used to assess school } \\
\text { going adolescents } \\
\text { problems and provide } \\
\text { them with family life } \\
\text { education. }\end{array}$ & $\begin{array}{l}\mathrm{n}=2781 \\
\text { Adolescents } \\
\text { randomly selected } \\
\text { from } 3 \text { rural and } 1 \\
\text { urban taluk }\end{array}$ & $\begin{array}{l}\text { No data available } \\
\text { around efficacy of } \\
\text { intervention. }\end{array}$ \\
\hline
\end{tabular}


Table 2. Community-based youth mental health interventions in India

\begin{tabular}{|c|c|c|c|c|}
\hline $\begin{array}{l}\text { Study name and } \\
\text { author }\end{array}$ & $\begin{array}{l}\text { Target } \\
\text { group }\end{array}$ & $\begin{array}{c}\text { Type of } \\
\text { intervention and } \\
\text { duration }\end{array}$ & Study design & Outcomes \\
\hline $\begin{array}{l}\text { Population based } \\
\text { intervention to } \\
\text { promote youth } \\
\text { health Goa, India; } \\
\text { Balaji et al., } \\
2011 \text { [21] }\end{array}$ & $\begin{array}{l}\text { Youth age } \\
16-24\end{array}$ & $\begin{array}{l}\text { Community } \\
\text { based inter- } \\
\text { vention designed } \\
\text { to promote youth } \\
\text { health Intervention } \\
\text { implemented over } \\
12 \text { months and } \\
\text { consists of } 3 \text { main } \\
\text { components: } \\
\text { (i) Peer Education } \\
\text { (ii) Teacher Training } \\
\text { (iii) Health } \\
\text { information } \\
\text { Intervention } \\
\text { implemented by } \\
\text { intervention team } \\
\text { which consisted of } \\
\text { social worker, two } \\
\text { psychologist and three } \\
\text { peer educators }\end{array}$ & $\begin{array}{l}\text { Exploratory } \\
\text { controlled } \\
\text { evaluation } \\
\mathrm{N}=1803 \text { students } \\
\text { from two urban } \\
\text { and rural } \\
\text { communities } \\
\text { Control } \\
\text { communities } \\
\text { were wait listed. } \\
18 \text { months follow } \\
\text { up }\end{array}$ & $\begin{array}{l}\text { Significant: } \\
\text { - decrease in probable depression } \\
\text { score (rural \& urban) } \\
\text { - greater knowledge and attitudes } \\
\text { about emotional health (rural) } \\
\text { - lower levels of suicidal behaviour } \\
\text { (urban)Peer leaders reported increase } \\
\text { in skills: } \\
\text { - selfconfidence } \\
\text { - leadership ability } \\
\text { - stress managements } \\
\text { - conflict resolution } \\
\text { - anger management and Improved } \\
\text { student-teacher relationship post- } \\
\text { intervention } \\
\text { Significant: } \\
\text { - increase in attitudes } \\
\text { aboutreproductive and sexual health } \\
\text { (rural \& urban) } \\
\text { - decrease in perpetration of physical } \\
\text { violence (rural \& urban) and } \\
\text { substance abuse (urban) } \\
\text { - Rural sample reported } \\
\text { Significant: } \\
\text { - fewer menstrual com-plaints } \\
\text { - higher levels of help } \\
\text { - seeking for reproductive and sexual } \\
\text { - RSH complaints } \\
\text { - menstrual complaints } \\
\text { lexual abuse }\end{array}$ \\
\hline $\begin{array}{l}\text { Panchayat Level } \\
\text { Primary-care } \\
\text { Approach; Nair et } \\
\text { al., } 2012 \text { [21] }\end{array}$ & $\begin{array}{l}13-19 \\
\text { years }\end{array}$ & $\begin{array}{l}\text { Anganwadi workers } \\
\text { (basic health care } \\
\text { worker) trained to } \\
\text { deliver following FLE } \\
\text { topics: adolescent } \\
\text { nutrition, personal } \\
\text { hygiene practices, } \\
\text { emotional education, } \\
\text { life skills, awareness } \\
\text { of own sexuality, } \\
\text { sexually transmitted } \\
\text { disease prevention, } \\
\text { substance abuse } \\
\text { prevention. }\end{array}$ & $\begin{array}{l}\mathrm{n}=2650 \\
\text { adolescents } \\
\text { Adolescents } \\
\text { selected from } \\
\text { intervention area }\end{array}$ & $\begin{array}{l}\text { No data available around efficacy of } \\
\text { intervention. }\end{array}$ \\
\hline
\end{tabular}

